\title{
JOB SATISFACTION AS A MEDIATION OF TRANSFORMATIONAL LEADERSHIP STYLE ON EMPLOYEE PERFORMANCE IN THE FOOD INDUSTRY IN MALANG CITY
}

\author{
Kenny Roz \\ Faculty of Economics and Business, University of Muhammadiyah Malang \\ Email: firdauskenny@umm.ac.id
}

\begin{abstract}
This research was conducted with the aim of testing the variable job satisfaction that mediated the effect of transformational leadership styles on employee performance in the food industry in Malang. The company guides each employee to improve their work performance. Leadership and satisfaction in work perceived by employees are considered to have a good impact on improving employee performance. This study uses a quantitative approach with a survey method. In this study using a saturated sample of 80 respondents were employees who were workers in food industry companies. The tool analysis in this study uses Partial Least Square (PLS). The results of this study, it was found that transformational leadership style and job satisfaction had a positive and significant influence on employee performance, and job satisfaction was able to mediate a positive relationship between transformational leadership scores on employee performance in the food industry in Malang.
\end{abstract}

Keywords: Transformational Leadership Style, Job Satisfaction, Employee Performance

\section{INTRODUCTION}

The food industry competition in the current era of globalization is getting tougher. Every food company competes to win the market. The right choice of strategy has been made by the company in achieving its objectives. It can be seen that more and more food industry businesses are making strategies to survive with similar competitors. This proves that if you don't do a good strategy, it is not impossible that the company will lose consumers and worse will be bankrupt. Community needs for a good and quality type of product demand that food industry businesspeople must continue to make improvements not only in terms of the final output or goods ready for sale but also from the management side.
The most important thing that must be done by a businessman in maintaining his business is to build healthy management to create a high performance (Veithzal, 2008). Various factors can influence the success of a company, some of which include the quality and quantity of human resources owned, leadership, job satisfaction felt by employees, etc. (Mathis and Jackson, 2006). Leadership in the food industry greatly affects the overall business activities up to decision making. With regard to this, it is very important that a leader must be able to position himself in the organization he leads. Leadership includes the ability someone has to encourage, direct, facilitate employees who are led to achieving agreed goals (Nurdin, 2011)

The leader must be able to inform, make, and evaluate related decisions and 
policies that must be carried out in the organization. By implementing an effective leadership style, a leader can manage wellowned resources. Bass and Avolio (1990) revealed that transformational leadership helps people to achieve their mission and renew their commitment to the stated goals. The leadership style in question is a leader who inspires his employees by putting aside their personal interests for the good of the organization and they are able to have a tremendous influence on their followers.

Another factor that affects a person at work is satisfaction. Job satisfaction describes the emotional state of employees regarding work, remembering what they expect and what they actually get from the organization. Muhammad et al. (2016) express job satisfaction that a person feels is seen through how a leader or company meets the needs of their employees. Someone who feels satisfied in his work will have the motivation, commitment to the organization or company and contribute to his work so that it will continue to improve their performance.

The purpose of this study is to see the extent to which employee performance is generated by the existence of transformational leadership style and job satisfaction on CV. Agar Sari Jaya Karangploso Malang. When an employee is satisfied with the achievements that have been obtained and facilitated by the leader, it can influence employee performance in an organization. This study took samples at CV. Agar Sari Jaya Karangploso Malang is one of the food industries in the poor city which is engaged in producing gelatin.

\section{LITERATURE REVIEW}

\subsection{Transformational Leadership Style and Employee Performance}

Leadership describes a person's ability to influence a group towards the goals to be achieved. Leadership illustrates how a person brings his organization in a better direction (Yukl, 2010). Leadership is often a means of discussion between management to make decisions. Leadership is a group of processes, personality, fulfillment, certain behaviors, persuasion, authority, the achievement of goals, interactions, different roles, structural initiation, and a combination of two or more of these things (Luthans, 2006). According to Burns (1978) the person who first put forward the idea, transformational leadership is a source of inspiration and vision for subordinates to bring change in an organization. Bass and Avolio (1990) revealed that transformational leadership helps people to achieve their mission and renew their commitment to the stated goals.

Performance is an actor from the whole level of planning to evaluation that utilizes resources that exist in organizations or companies (Kreitner and Kinicki, 2005). Quality, quantity, soft skill development and discipline in work are the factors that support someone in working as mentioned by (Sudarmanto, 2009). The existence of a good relationship between leadership and employees inspires healthy management. The absence of gaps between leaders and employees will create a conducive working atmosphere that will impact the achievement of an organization or company

Research conducted by (Bass and Avolio, 1997) Transformational leaders facilitate employee performance and to achieve their goals by using 4 components, namely: inspirational, charismatic, intellectual 
stimulus, and individual attention. Furthermore, the research study conducted by (Ndrirangu, 2018) shows that there is a positive thing that happens between transformational leadership styles towards employee performance. Other research shows that the transformational leadership style model has a positive influence on employee performance (Wiratmadja et al., 2008).

\subsection{Transformational Leadership Style and Job Satisfaction}

The concept of job satisfaction in an organization is seen as a feeling that can produce positive or negative effects on someone's roles and responsibilities at work. Job satisfaction can also be defined as the emotional response of workers to jobs that are charged (Ndulue and Ekechukwu, 2016). Job satisfaction describes the emotional state of employees regarding work, remembering what they expect and what they actually get from the organization. According to Maslow the theory of need is divided into several, among others: (1) Physiological needs include basic needs, thirst, hunger, shelter, sleep, and other physical needs, (2) Security needs include safety and physical and mental protection, (3) Social needs include receiving in the environment, needs will be loved and loved, and friendship. (4) The need for rewards includes self-esteem, achievement in work, respect for others, and (5) Selfactualization includes being yourself and being anything with his abilities.

Long et al. (2014) explain the relationship between transformational leadership style and job satisfaction. High job satisfaction is indicated by the ability of a leader. In this connection, a leader provides support, opportunities, assistance, and benefits for the benefit of employees. In a study conducted by Muhammad et al. (2016) explain the relationship between transformational leadership style and job satisfaction both partially and simultaneously. Similar results are shown by individual attention and intellectual stimuli provide good effects and affect the level of employee satisfaction.

\subsection{Transformational Leadership Style, Job Satisfaction, and Employee Performance}

Employee performance is defined as the work of someone who is reviewed and the quality and quantity achieved by a worker in completing the task and in accordance with his responsibilities. Employee performance is considered important because it can be a measure of the success of an organization. Based on Fadlallah's research (2015) reveals the existence of a positive and significant relationship between the workability and performance of employees. This study concluded that every working condition, wages and promotions increased, similar things resulted in improving employee performance. This is reinforced by the research conducted by Inuwa (2016) which proves that the factors in job satisfaction have a good impact on workers when completing a given task.

\section{METHODOLOGY}

\subsection{Types of Research}

This research is quantitative explanatory research based on theories or hypotheses to test a phenomenon that occurs (Cooper and Schindler, 2006). Primary data collection techniques use questionnaires directly to respondents. The list of questions asked includes items of transformational leadership 
style variables, job satisfaction and employee performance.

\subsection{Sample}

Sample in this study were employees of CV. Agar Sari Jaya Karangoploso Malang. This study uses saturated samples where all employees working on CV. Agar Sari Jaya of 80 were made respondents.

\subsection{Operation Definition}

There are three variables used in this study, Transformational Leadership Style (X1), Job Satisfaction (X2) as an independent variable, while the performance of employees as dependent variables. Transformational leadership style is the ability of a leader to influence employees below to achieve the desired goals. Furthermore, Khan and Nawaz (2017) leadership style is a way of giving direction, implementing strategies and motivating individuals towards achieving the desired goals. The dimensions of the terrorist leadership style of Robbins and Judge (2008) are (1) inspirational, (2) charismatic, (3) intellectual stimulus, (4) attention to individuals. This is reinforced by research conducted by (Hanaysha et al., 2012) and (Metwally and El-bishbishy, 2014).

Job Satisfaction (X2) in this study is a mediating variable which means connecting or mediating between independent and dependent variables. Job Satisfaction sorted by Robbins and Judge (2008) job satisfaction is a general attitude that exists in each individual to his work. Furthermore, according to Hasibuan (2009) job satisfaction refers to the general attitude of an individual to the work he does. Someone with a high level of job satisfaction shows a positive attitude towards the performance itself. According to Maslow's theory the dimensions of one's job satisfaction can be seen in several aspects, namely: (1) Physiological needs include basic needs, thirst, hunger, shelter, sleep, and other physical needs, (2) Security needs include safety and physical protection and mental, (3) Social needs include receiving in the environment, needs will be loved and loved, and friendship. (4) The need for rewards includes self-esteem, achievement in work, respect for others, and (5) Selfactualization includes being yourself and being anything with his abilities.

Employee performance variable (Y) is the dependent variable in this study. Employee performance according to Mangkunegara (2006) is the work of a person who is reviewed and the quality and quantity achieved by a worker in completing the task and in accordance with his responsibilities. In the theory put forward by Sudarmanto (2009) the dimensions of employee performance can be: (1) Quality, (2) Quantity, (3) Knowledge and Skills, and (4) Timeliness.

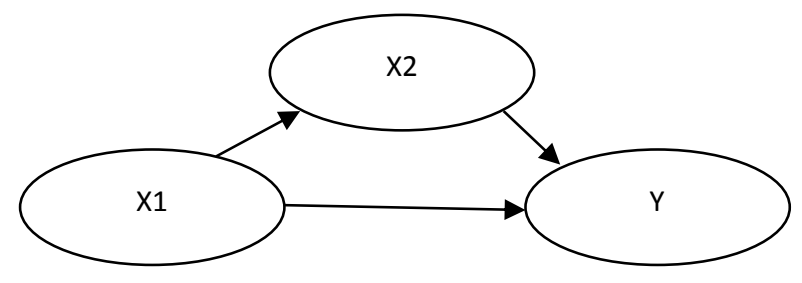

Figure 1 : Conceptual Framework od Reseach 


\section{RESULT AND DISCUSSION}

\subsection{Measurement Evaluation}

In this study two stages of analysis were carried out, namely the evaluation of the measurement model (outer model) and the structural model (inner model). Before further analysis, it is necessary to test validity and reliability. The first stage, to assess convergent validity, is used to measure internal consistency accordingly, namely reliability of accounting calculated by the alpha coefficient, composite reliability, average variance extracted (AVE) for each construct. The criteria used is to prove that discriminant validity is acceptable. The results of the average variance extracted (AVE) from this study can be seen from the following table:

Table 1

Results of Average Variance Extracted (AVE)

\begin{tabular}{l|c}
\hline \multicolumn{1}{c|}{ Variable } & AVE \\
\hline Transformational leadership style (GKT) & 0,770 \\
\hline Job Satisfaction (KUP) & 0,635 \\
\hline Employee performance (KK) & 0,603 \\
\hline
\end{tabular}

From table 1, the evaluation of the AVE measurement model shows that the AVE value for each variable is above 0.5. Based on the table above, the average variance extracted (AVE) value in the transformational leadership style (GKT) value is 0.770 , job satisfaction (KUP) is 0.635 , and employee performance $(\mathrm{KK})$ is 0.603 . It can be concluded that discriminant validity, the measurement model is quite good.

\subsection{Validity Test}

To test whether each indicator is valid or not by looking at the coefficient of arithmetic between question items with the total value compared with the value of $r$ table. If $r$ count is greater than $r$ table and positive value then the item or item question is declared valid. The level of error significance used in this study is $\alpha=5 \%$.

Table 2

Result of Validity Test

\begin{tabular}{c|c|c|c}
\hline Variable & Indicator & Result test & Information \\
\hline \multirow{4}{*}{ X1 } & $\mathrm{X} 1.1$ & 0,80 & Valid \\
\cline { 2 - 4 } & $\mathrm{X} 1.2$ & 0,845 & Valid \\
\cline { 2 - 4 } & $\mathrm{X} 1.3$ & 0,905 & Valid \\
\cline { 2 - 4 } & $\mathrm{X} 1.4$ & 0,878 & Valid \\
\hline \multirow{5}{*}{} & $\mathrm{X} 2.1$ & 0,770 & Valid \\
\cline { 2 - 4 } & $\mathrm{X} 2.2$ & 0,852 & Valid \\
\cline { 2 - 4 } & $\mathrm{X} 2.3$ & 0,700 & Valid \\
\hline
\end{tabular}




\begin{tabular}{c|c|c|c}
\hline \multirow{3}{*}{ X2 } & X2.4 & 0,733 & Valid \\
\cline { 2 - 4 } & $\mathrm{X} 2.5$ & 0,816 & Valid \\
\hline \multirow{4}{*}{ Y } & Y1.1 & 0,950 & Valid \\
\cline { 2 - 4 } & Y1.2 & 0,673 & Valid \\
\cline { 2 - 4 } & Y1.3 & 0,530 & Valid \\
\cline { 2 - 4 } & Y1.4 & 0,949 & Valid \\
\hline
\end{tabular}

\subsection{Reliability Test}

The items distributed must be tested for validity and reliability using SPSS version 24 . In this reliability analysis using Cronbach alpha 0.7. The following results of the reliability test for all variables can be seen in the table below:

Table 3

Result of Reliability Test

\begin{tabular}{c|c|c}
\hline Variable & Comp. Reliability & Cronbach Alpha \\
\hline GKT & 0.900 & 0930 \\
\hline KUP & 0.791 & 0.868 \\
\hline KK & 0,835 & 0,883 \\
\hline
\end{tabular}

From table 3 shows the results of measurement data using the composite ability, to determine whether the construct has high reliability over no. The composite reliability value $>0.70$ states that the construct is reliable while the Cronbach alpha value is> 0.70 . Based on the table of data, it can be seen that the composite reliability value in the variable transformational leadership style (GKT) is 0.900, job satisfaction (KUP) 0.791, and employee performance of 0.835 is greater than 0.70 and can be collected reliably the measurement results in this study is good.

\subsection{Measurement of the Structure Model}

After the model estimated meets the criteria of convergent validity and discriminant validity, the next is to test the structural model (inner model). Through the inner model is to see the relationship between latent constructs by looking at the results of the estimation of path parameter coefficients and their level of significance (Ghozali, 2013). The results of the coefficient of determination (R-Square) from this study can be seen in the following table: 
Table 4

Result of $R$-Square

\begin{tabular}{c|c}
\hline Effect & R-Square \\
\hline GKT $\rightarrow$ KK & 0,613 \\
\hline GKT $\rightarrow$ KUP & 0,656 \\
\hline
\end{tabular}

In table 4 the deterrence coefficient (RSquare) obtained from the results of data collection from the GKT model for KK of 0.613 states that employee performance is able to explain the transformational leadership style of $61.3 \%$, and the GKT model of KUP of 0.656 states that job satisfaction is able explained transformational leadership style of $65.6 \%$. In this research, the structural model used is relatively strong.

\subsection{Hypothesis Test}

This study examines the significance of the path coefficient using partial least square (PLS), the path coefficient shows the magnitude of the influence of independent variables on the dependent variable. If the significant path coefficient value can be stated that the independent variable has a significant effect on the dependent variable.

Tabel 5

Direct and Indirect Effect Between Variables $(\mathrm{N}=80)$

\begin{tabular}{c|c|c|c|c|c|c}
\hline & $\begin{array}{c}\text { Origin } \\
\text { al } \\
\text { Sample } \\
(\mathbf{O})\end{array}$ & $\begin{array}{c}\text { Sample } \\
\text { Mean } \\
(\mathbf{M})\end{array}$ & $\begin{array}{c}\text { Standard } \\
\text { Deviation } \\
\text { (STDEV) }\end{array}$ & $\begin{array}{c}\mathbf{T} \\
\text { Statisti } \\
\mathbf{c s} \\
(\mathbf{O} / \mathbf{S T} \\
\mathbf{E R R})\end{array}$ & p-value & $\begin{array}{c}\text { Informati } \\
\text { on }\end{array}$ \\
\hline $\begin{array}{c}\text { GKT }- \\
\text { >KK }\end{array}$ & 0,318 & 0,314 & 0,123 & 2,590 & 0,010 & Sig. \\
\hline $\begin{array}{c}\text { GKT-> } \\
\text { KUP }\end{array}$ & 0,810 & 0,814 & 0,036 & 22,276 & 0,000 & Sig. \\
\hline $\begin{array}{c}\text { KUP-> } \\
\text { KK }\end{array}$ & 0,503 & 0,509 & 0,118 & 4,267 & 0,000 & Sig. \\
\hline $\begin{array}{c}\text { GKT- } \\
\text { >KUP- } \\
>\text { KK }\end{array}$ & 0,407 & 0,415 & 0,098 & 4,147 & 0,000 & Sig. \\
\hline
\end{tabular}

Information:

GKT $=$ Transformational Leadership Style

KUP $=$ Job Satisfaction

$\mathrm{KK}=$ Employee Performance

From the results in table 4 shows that the statistical value of the first test is greater than the value of $t$ table $(2.590>1.960)$, this indicates that the transformational leadership style has a positive and significant effect on employee performance. For the second test, 
the $\mathrm{t}$ statistic is greater than $\mathrm{t}$ table $(22,276>$ 1,960), this shows that the transformational leadership style has a positive and significant effect on job satisfaction. For the third test, the $\mathrm{t}$ statistic is greater than t table (4.267> 1.960), this means that job satisfaction has a positive and significant effect on employee performance. For the 4th test, the statistical value is greater than $t$ table $(4,147>1,960)$, this proves that job satisfaction is able to mediate the effect of transformational leadership style on employee performance. From the overall test results, it can be concluded that all independent variables have a positive and significant effect on the dependent variable.

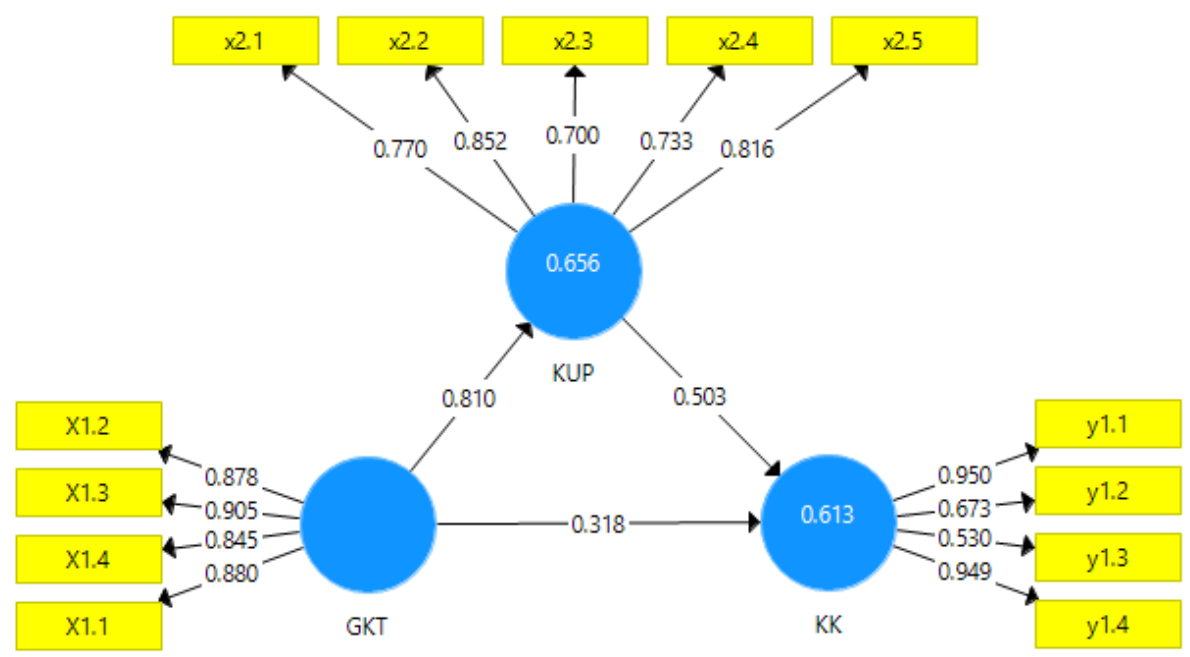

Figure 2: Test Results using PLS

Based on the results of research and data processing, the following will be discussed further on the results of the research conducted by the researcher :

\subsubsection{Effect of transformational leadership style on employee performance}

According to the results of testing the hypothesis, there is a positive and significant effect of transformational leadership on employee performance. With the implementation of a transformational leadership style, employee performance is increasing. The presence of leadership that inspires makes employees feel capable of completing assigned tasks. Not only that, but employees also assess the presence of an intellectual stimulus that their managers feel is able to solve problems in their own way. This research is supported by research conducted by Al-Amin (2017) that there is a positive relationship that occurs between transformational leadership styles on employee performance. This research is also reinforced by the findings of Andreani and Petrik (2016) that transformational leadership style has a significant positive effect on employee performance. Based on the results of 
research conducted in the food industry $\mathrm{CV}$. Agar Sari Jaya Karangploso Malang shows that by applying a transformational leadership style that has a good impact on employee performance. The better the leadership style that is applied, the higher the employee's performance on the CV. Agar Sari Jaya Karangploso Malang. Maanjer not only provides assignments and workloads, but managers also provide solutions to problems faced by employees.

\subsubsection{Effect of transformational leadership style on job satisfaction}

According to the results of testing the hypothesis in table 4 shows that the influence of transformational leadership style on job satisfaction has a significant effect. The results of the analysis show that transformational leadership style can have a positive and significant effect on job satisfaction. This research is supported by research conducted by Long et al. (2014) that a leader who applies a transformational leadership style has a positive effect on satisfaction at work. Achieving employee job satisfaction is very important to maintain productive and efficient employees. The four characteristics of transformational leadership that are idealized such as influence, motivational inspiration, intellectual stimulation, and individual consideration greatly help employees in achieving satisfaction. In line with other studies Muhammad et al. (2016) support the transformational leadership style to have a positive impact on a worker to feel fast in carrying out his duties.

Based on observations on a CV. In Agar for Sari Jaya Karangploso Malang, all employees are satisfied in working because the desires and expectations of the manager can be realized such as fulfilling their physiological needs, giving awards for the achievements, providing security to employees and freeing their employees to be proactive and explore the knowledge and skills they have.

\subsubsection{Effect of Job Satisfaction on Employee Performance}

Based on the results of testing the hypothesis, the effect of job satisfaction on employee performance has a significant influence on employee performance. This study has similarities done by Ndulue and Ekechukwu (2016), there is a direct relationship between the workforce and employee performance. Other researchers also reinforce the findings of this result, Khan et al. (2012) that job satisfaction can encourage someone to immediately work out the responsibilities delegated to him and resolve according to the time specified.

Besides this based on observations of CV. Agar Sari Jaya Karangploso Malang, that job satisfaction has a very large role in the process of improving employee performance. The existence of a program that is given by management to employees requires that employees respond well to it, such as the provision of appropriate salaries, incentives, health insurance, awards for achievement, encouraging employees to work better. The higher the job satisfaction that is felt by employees, the employee's performance on the CV. So that Sari Jaya Karangploso Malang is also getting higher. 


\subsubsection{Job satisfaction is able to mediate the influence of transformational leadership style on employee performance}

According to the results of testing the hypothesis in this study, job satisfaction is able to mediate the effect of transformational leadership style on employee performance. The ability of job satisfaction provides a positive and significant influence between the transformational leadership style on employee performance. This is in line with the research conducted by Prabowo et al. (2018) that job satisfaction is able to become the link between the influence of transformational leadership style on employee performance. Another study was conducted by Chang (2017) and (Andreani and Petrik (2016)) this study found that job satisfaction has the ability to mediate the influence on the relationship between leadership style and job performance.

Observation on a CV. In Agar for Sari Jaya Karangploso Malang with that, the transformational leadership style that is applied and the working power felt by employees is a very important factor in improving employee performance. The nature of a leader who has charismatic, able to make an inspiration, can provide intellectual stimulus and provide individual attention to give a sense of satisfaction in an employee at work. The sense of security created in work, fulfilling the physiological needs of employees, giving awards for the achievements made by the manager of $\mathrm{CV}$ Agar Sari Sari Jaya Karangploso has a positive impact on the relationship between leaders and employees.

\section{Result}

The purpose of this study was to discuss the transformational leadership style on job satisfaction and employee performance in the food industry in Malang. Positive and significant relationships were obtained to the three variables used. Based on the results of the statistical tests and discussions that have been agreed upon, it can be concluded that the transformational leadership style has a positive and significant influence on job satisfaction and the impact on improving company performance on a CV. Agar Sari Jaya Karangploso Malang. The same results also show job satisfaction influences employee performance and are able to mediate between transformational leadership style and employee performance on a CV. Agar Sari Jaya Karangploso Malang. The findings of this study support research conducted previously by other researchers. The better the leadership style that is applied to the company, the satisfaction in the work that is felt by the employee will have a good effect on completing the work that has been given.

\section{Conclusion}

The results showed that each of the 2 independent variables of transformational leadership style and job satisfaction had a positive with dependent variable employee performance on a CV. Agar Sari Karangploso Malang. The Transformation Leadership Style applied by a leader supports both those who give a good commitment to employee performance on the CV. Agar Sari Karangploso Malang. The four dimensions that form a transformational leadership style are inspirational, charismatic, intellectual stimulation, attention to individuals who have 
a positive influence on employees to be satisfied at work. the satisfaction that employees receive at work, give a good effect on performance.

Another thing found in this study is job satisfaction that is able to mediate the transformational leadership style on employee performance. The greater the satisfaction in work, the greater the influence of leaders in increasing employees to improve their performance. For the future advice that can be given is to maintain a transformational leadership style such as individual attention to employees, provide intellectual stimulus to employees to always develop skills both from hard / soft skills, and provide programs that can be felt by employees for the achievements so that in work employees feel satisfied and remain loyal to the company.

\section{REFERENCES}

Al-Amin, M. 2017. Transformational Leadership and Employee Performance Mediating Effect of Employee Engagement. NorthSouth Business Review, 7, 28-40.

Andreani, F. \& Petrik, A. 2016. Employee Performance as The Impact of Transformational Leadership and Job Satisfaction in PT. Anugerah Baru Denpasar. JURNAL MANAJEMEN DAN KEWIRAUSAHAAN, 18, 25-32.

Bass, B. M. \& Avolio, B. J. 1990. Developing Transformational Leadership: 1992 and Beyond. Journal of European Industrial Training, 14.

Bass, B. M. \& Avolio, B. J. 1997. Does the Transactional Transformational Leadership Paradigm Transcend Organizational and National Boundaries? American Psychologist, 52, 130-139.
Burns, J. M. 1978. Leadership, Newyork, Harper \& Row.

Chang, H. 2017. Does Leadership Matter? Study of Leadership Style, Job Performance and Job Satisfaction. POSLOVNA EKONOMIJA BUSINESS ECONOMICS Godina XI, 2, 128.

Cooper \& Schindler, P. S. 2006. Metode Riset Bisnis (Budijanto, D. Djunaedi, D. Sihombing \& Penerjemah, Trans. 9 ed.). Jakarta, PT Media Global Edukasi.

Fadlallh, A. W. A. 2015. Impact of Job Satisfaction on Employees Performance an Application on Faculty of Science and Humanity Studies University of Salman Bin Abdul-Aziz-Al Aflaj. International Journal of Innovation and Research in Educational Sciences, 2, 2349-5219.

Ghozali, I. 2013. Model Persamaan Struktural Konsep \& Aplikasi Amos 21.0 (Edisi tujuh ed.), Semarang, Badan Penerbit Universitas Dipenogoro.

Hanaysha, J., Mat, N. K. N., Mehmood, K. K. \& Sarassina, F. 2012. Transformational Leadership and Job Satisfaction. American Journal of Economics

Hasibuan, M. 2009. Manajemen Sumber Daya Manusia, Jakarta, PT. Bumi Aksara.

Inuwa, M. 2016. Job Satisfaction and Employee Performance: An Empirical Approach. The Millennium University Journal, 1.

Khan, A. H., Nawaz, M. M., Aleem, M. \& Hamed, W. 2012. Impact of job satisfaction on employee performance: An empirical study of autonomous Medical Institutions of Pakistan. African Journal of Business Management, 6, 2376-2705.

Khan, I. \& Nawaz, A. 2017. The Leadership Styles and The Employees Performance: A Review Gomal University Journal of Research [GUJR], 32. 
Kreitner, R. \& Kinicki, A. 2005. Perilaku Organisasi, Jakarta, Salemba Empat.

Long, C. S., Mardhia, W., Yusof, M., Kowang, T. O. \& Heng, L. H. 2014. The Impact of Transformational Leadership Style on Job Satisfaction. World Applied Sciences Journal, 29, 117-124.

Luthans, F. 2006. Perilaku Organisasi, Yogyakarta, Penerbit Andi.

Mangkunegara, A. A. A. P. 2006. Evaluasi Kinerja SDM, Bandung, PT. Refika Aditama.

Mathis, R. L. \& Jackson, J. H. 2006. Manajemen Sumber daya Manusia Jakarta, Salemba Empat.

Metwally, A. H. \& El-Bishbishy, N. 2014. The Impact of Transformational Leadership Style on Employee Satisfaction. The Business \& Management Review, 5, 32-42.

Muhammad, R., Djudi, M. \& Mayowan, Y. 2016. Pengaruh Gaya Kepemimpinan Transformasional dan Traksaksional Terhadap Kepuasan Kerja (Studi pada CV Kalingga Jaya di Jakarta). Jurnal Administrasi Bisnis (JAB), 35, 110-119.

Ndrirangu, J. W. 2018. Influence Of Transformational Leadership On Employee Performance: A Case Study Of Local NonGovernmental Organizations In Kenya. Africa: UNITED STATES INTERNATIONAL UNIVERSITY.

Ndulue, T. I. \& Ekechukwu, H. C. 2016. Impact of Job Satisfaction on Employees Performance: A Study of Nigerian Breweries PLC Kaduna State Branch Nigeria. Kuwait Chapter of Arabian Journal of Business and Management Review, 5, 13-23.

Nurdin, A. 2011. Pengaruh Gaya Kepemimpinan Transformasional dan Kompensasi Terhadap Kinerja Karyawan Dengan Motivasi Kerja Sebagai Variabel Moderating (Studi Kasus PT. TELKOM
Kandatel Ternate). Universitas Muhammadiyah malang.

Prabowo, T. S., Noermijati \& Irawanto, D. W. 2018. The Influence Of Transformational Leadership And Work Motivation On Employee Performance Mediated By Job Satisfaction. Journal of Applied Management (JAM), 16, 171-178.

Sudarmanto 2009. Kinerja dan Pengembangan Kompentensi Sumber Daya Manusia, Yogyakarta, Pustaka Belajar.

Veithzal, R. 2008. Manajemen Sumber Daya Manusia Untuk perusahaan : dari Teori dan Praktik, Jakarta, PT. RajaGrafindo Persada.

Wiratmadja, I. I., Govindaraju, R. \& Rahyuda, A. G. The Influence of Transformational Leadership Style and Compensation System on the Performance of University Lecturer A Case at a State University in Indonesia. Proceedings of the 9th Asia Pacific Industrial Engineering \& Management Systems Conference (APIEMS), 2008 Nusa Dua, Bali. 